\title{
Quinsy tonsillectomy in the management of peritonsillar abcess in children
}

\author{
Tonsilectomia la cald în flegmonul periamigdalian la copil \\ Veronica EPURE ${ }^{1,2}$, Dan Cristian GHEORGHE ${ }^{1,2}$ \\ ${ }^{1}$ Spitalul Clinic de Urgență pentru Copii „M.S. Curie“, Bucureşti, România \\ ${ }^{2}$ Universitatea de Medicină şi Farmacie „Carol Davila“, Bucureşti, România
}

\section{ABSTRACT}

The treatment of peritonsillar abcess in children is controversial: it consists either of immediate drainage followed by interval tonsillectomy, either of immediate tonsillectomy (abcess tonsillectomy or quinsy tonsillectomy). The authors report 3 cases of quinsy tonsillectomy performed in children with peritonsillar abcesses.
\end{abstract}

Keywords: punction and drainage, quinsy tonsillectomy, interval tonsillectomy, postoperative hemorrhage

\section{REZUMAT}

Tratamentul flegmonului periamigdalian la copil implică întotdeauna un management chirurgical: fie drenaj de urgență, urmat de amigdalectomie la distanță, fie amigdalectomie la cald în cazuri selecționate. Autorii aduc in discuție 3 cazuri de amigdalectomie la cald în flegmoane periamigdaliene la copil.

Cuvinte cheie: incizie-drenaj, amigdalectomie la cald, amigdalectomie la rece, sângerare postoperatorie

\section{INTRODUCERE}

Flegmonul periamigdalian (FPA) este o infecție localizată între capsula amigdalei palatine și mușchiul constrictor superior al faringelui. Este cea mai frecventă formă de supurație la nivel craniocervical, întâlnită mai ales la adolescenți și adulți tineri, rar la copil, extrem de rar la sugar.

Tratamentul flegmonului periamigdalian ridică unele controverse $(1,2)$ : în afară de tratamentul medical (antibioterapie intravenoasă cu spectru larg), implică întotdeauna și tratament chirurgical (clasic, se practică puncția colecției, urmată de incizia și drenajul flegmonului sub anestezie locală sau generală, în funcție de vârsta pacientului, urmată de amigdalectomie la rece, la 3-6 săptămâni de la stingerea fenomenelor inflamatorii acute; alternativ, se poate practica amigdalectomia imediată sau la cald).

Sintetizând datele din literatura de specialitate disponibile între 1994 și 2019 (1-5), care cuprind studii comparative pe loturi de 34-51 cazuri copii cu flegmon periamigdalian tratați prin amigdalectomie la cald ver- 
sus antibioterapie, drenaj și amigdalectomie la rece la distanță, putem observa că: sângerarea intraoperatorie este identică în cele două situații, tehnica operatorie este mai simplă pentru amigdalectomia la cald (nu există încă aderențe peritonsilare ca în cazul flegmonului răcit), durata spitalizării este mai redusă pentru amigdalectomia la cald (în medie 3 versus 4,5 zile postintervențional), durata convalescenței este semnificativ mai redusă pentru amigdalectomia la cald (10 versus 17,3 zile), durerea postoperatorie este mai redusă după amigdalectomia la cald față de amigdalectomia tardivă după flegmon (măsurată pe scala OPS objective pain scale), durerea postoperatorie după amigdalectomia la cald e similară cu cea după amigdalectomia la rece fără flegmon. Durata operației în cele două situații este similară, iar complicațiile postoperatorii (în special redutabila hemoragie postoperatorie) sunt similare.

\section{PREZENTĂRILE CAZURILOR}

În clinica ORL a Spitalului de Urgență pentru Copii „M.S. Curie“, București, pe o durată de 28 luni (octombrie 2017 - ianuarie 2020), am amigdalectomizat la cald 9 pacienți cu flegmon periamigdalian. Dintre aceștia, am ales trei cazuri ilustrative pentru această metodă de tratament al flegmonului periamigdalian.

\section{Cazul 1}

Pacientul M.M., în vârstă de 12 ani, se prezintă cu flegmon periamigdalian stâng, după tratament de 7 zile în ambulator cu Zinnat; prezentarea clinică s-a făcut cu odinofagie, febră, trismus, sialoree, adenită, torticolis, refuzul alimentației. Diagnosticul s-a stabilit clinic (pe aspectul bucofaringoscopic).
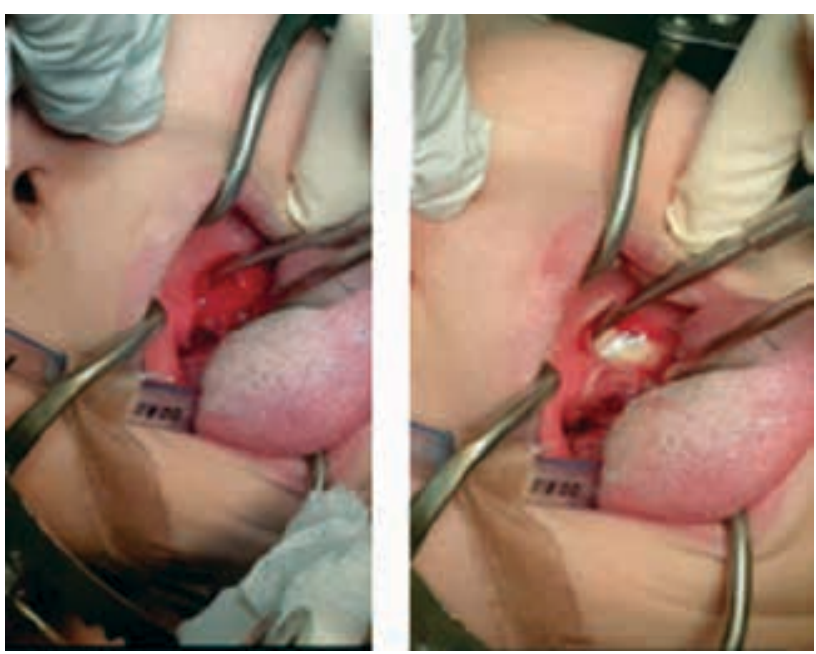

FIGURA 1. Tehnica amigdalectomiei la cald. Incizia pilierului amigdalian anterior şi decolarea cu punerea în evidență a colecției din spațiul paraamigdalian

Se practică inițial puncție, urmată de incizia și drenajul flegmonului sub anestezie generală, cu evoluție

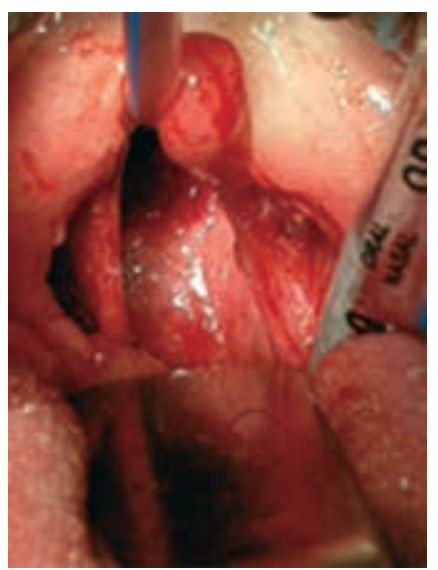

FIGURA 2. Aspect imediat postoperator după amigdalectomie la cald în cazul 1 - discret edem al lojii amigdaliene stângi, fără sângerare locală

staționară sub tratament antibiotic intravenos (Cefuroxime 100 mg/kc/zi și Gentamicină 4 mg/kgc/zi). Persistă tumefacția laterofaringiană și odinofagia la 24 ore. Se efectuează CT cervical, cu evidențierea unei colecții profunde paraamigdaliene stângi. Se decide și practică amigdalectomie la cald (bilaterală), cu evoluție imediat favorabilă și externare la 3 zile.

Amigdalectomia la cald a fost tehnic simplă, urmând aceiași pași ca în cazul unei amigdalectomii clasice, decolarea amigdalei a decurs cu ușurință, diferența între cele două tipuri de amigdalectomii a constat în „valul de puroi“ care a inundat plaga în momentul decolării amigdalei cu flegmon la cald (figura 1). Aspectul lojei postamigdalectomie la cald este similar cu cel după o amigdalectomie la rece, cu prezență de minim edem și tumefacție locală (figura 2).

\section{Cazul 2}

Pacientul A.S., în vârstă de 15 ani, cu diagnosticul de flegmon periamigdalian stâng anterior și posterior, prezentat în clinică după tratament ambulator cu Zinnat per os 7 zile și Klacid per os 7 zile, cu evoluție nefavorabilă; se prezintă cu odinofagie, febră, trismus, dificultăți de alimentație, sindrom biologic inflamator acut sugestiv pentru infecție bacteriană; se decide și se practică amigdalectomie unilaterală stângă, fără incidente intra- și postoperatorii, urmată de antibioterapie intravenoasă, apoi externare după 3 zile și antibioterapie per os la domiciliu; evoluție favorabilă. În acest caz, am ales amigdalectomia unilaterală la cererea aparținătorului, acesta motivând absența episoadelor amigdaliene acute anterior internării actuale; de asemenea, am luat în considerare reducerea riscului unei posibile hemoragii postoperatorii, limitându-ne la o singură lojă.

\section{Cazul 3}

Pacientul C.A., în vârstă de 15 ani, se prezintă cu flegmon periamigdalian drept anterior și posterior; ini- 
țial, se practică incizie și drenaj sub anestezie locală, urmată de antibioterapie intravenoasă; colecția recidivează, repetându-se procedura de drenaj sub anestezie locală după 7 zile; urmează o nouă recidivă locală, după 7 zile pacientul prezentându-se cu colecție periamigdaliană posterioară fuzată laterofaringian dreapta. Se efectuează CT craniocervical nativ și cu substanță de contrast (figura 3 - arată colecție paraamigdaliană dreaptă). Se decide amigdalectomie imediată bilaterală. În urma amigdalectomiei, s-a constatat prezența unei fistule pe pilierul amigdalian posterior (figura 4), cu exteriorizare de puroi în momentul decolării extracapsulare a amigdalei palatine drepte. Evoluția postoperatorie, sub antibioterapie intravenoasă, a fost favorabilă.

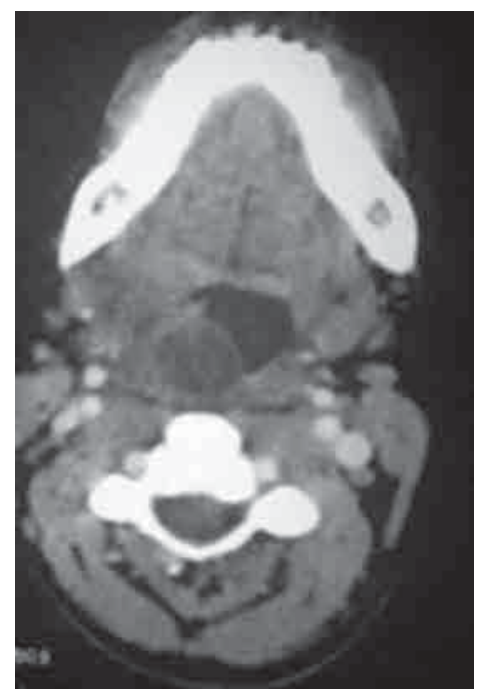

FIGURA 3. Aspectul tomografic al unui flegmonului periamigdalian drept din cazul 3

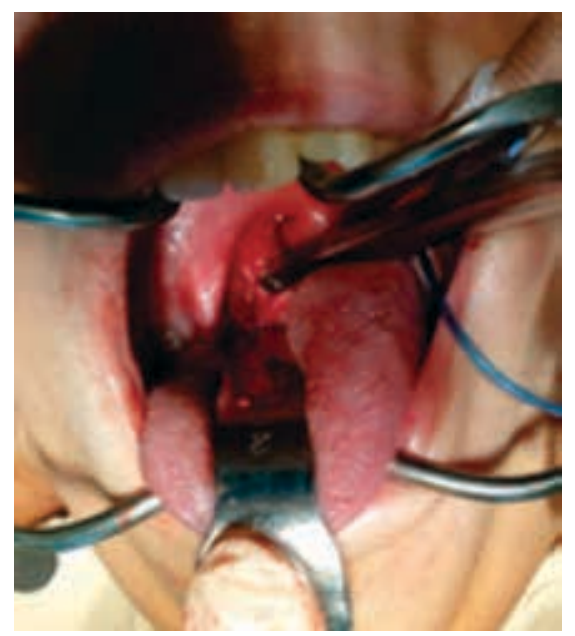

FIGURA 4. Aspecte postoperatorii după amigdalectomia la cald: orificiu fistulos la nivelul pilierului amigdalian posterior în cazul 3

\section{DISCUȚII}

Sângerarea intraoperatorie măsurată la pacienții noștri prin numărul de comprese folosite și prin durata medie a hemostazei locale postamigdalectomie nu a fost diferită față de situația unei amigdalectomii obișnuite; sângerări imediate în primele 24 ore sau tardive la 7-10 zile postoperator nu s-au înregistrat la pacienții amigdalectomizați la cald, în concordanță cu datele din literatură, majoritatea studiilor consemnând mai degrabă sângerări din loja controlaterală în cazurile de amigdalectomie la cald (6) - motiv pentru care am propus amigdalectomie unilaterală în unele situații. Durerea postoperatorie a fost similară; evoluția postoperatorie a fost rapid favorabilă la pacienții cu amigdalectomie la cald, externarea lor în stare bună făcându-se la 2-3 zile postoperator în toate cazurile, comparativ cu perioada de 4-5 zile de spitalizare obișnuită în cazul pacienților la care s-a practicat doar drenajul flegmonului (la acestea adăugându-se și cele 1-2 zile petrecute în spital cu ocazia amigdalectomiei la rece).

Amigdalectomia la cald pare astfel o metodă sigură și eficientă de tratament în flegmonul periamigdalian la copil, care nu se recomandă de elecție în flegmonul periamigdalian, dar este de preferat în anumite cazuri deoarece: este o procedură unică, simplă tehnic, are ca efect scăderea imediată a durerii (ameliorând calitatea vieții pacientului), complicațiile intra- și postoperatorii sunt similare cu ale amigdalectomiei la rece, durata spitalizării, a convalescenței și a tratamentului cu antibiotice este mai scăzută în cazul intervenției la cald. Tonsilectomia la cald este indicată doar în cazurile ce nu răspund la alte tipuri de tratament $(7,8)$; există actualmente studii care arată că nici tonsilectomia la distanță după flegmonul periamigdalian nu este o procedură de rutină (folosită de unii autori în caz de complicații majore, de exemplu fasceită necrozantă ca urmare a unui flegmon periamigdalian).

La examenul bacteriologic al puroiului din colecție recoltat intraoperator la cazurile noastre, s-a decelat Streptococcus pyogenes, cu sau fără anaerobi. Incidența crescută a germenilor anaerobi în flegmonul periamigdalian ar sugera că drenajul suficient de larg este esențial în rezolvarea acestei patologii (9), iar în situațiile de flegmon profund acest drenaj larg a fost asigurat doar prin excizia amigdalei de partea colecției.

Am constatat uneori recidive locale ale flegmonului periamigdalian în cazul pacienților tratați inițial prin drenajul flegmonului periamigdalian și antibioterapie, acestea de multe ori împiedicând revenirea pacientului în clinică pentru amigdalectomie la rece la distanță. Amigdalectomia la cald poate permite soluționarea rapidă și definitivă a flegmonului.

Printre dezavantajele citate în literatură ale metodei cităm: risc anestezic mai mare, risc de sepsis, risc de rupere a abcesului și aspirație la intubație; la pacienții cu flegmon periamigdalian amigdalectomizați în clinica noastră, nu am constatat niciun incident intraoperator sau postoperator. 


\section{CONCLUZII}

Considerăm astfel că amigdalectomia la cald este o metodă sigură și eficientă de tratament în flegmonul periamigdalian la copil, o procedură unică, simplă teh-

Conflict of interest: none declared

Financial support: none declared nic; nu recomandăm de elecție amigdalectomia la cald în caz de flegmon periamigdalian, dar trebuie avută în vedere în anumite cazuri.

\section{BIBLIOGRAFIE}

1. Fagan JJ, Wormald. PJ. Quinsy tonsillectomy or interval tonsillectomy - a prospective randomised trial. $S$ Afr Med J. 1994 Oct;84(10):689-90.

2. Lockhart R, Parker GS, Tami TA. Role of quinsy tonsillectomy in the management of peritonsillar abcess. Ann Otol Rhinol Laryngol. 1991 Jul;100(7):569-71.

3. Page C, Chassery G, Boute P, Obongo R, Strunski V. Immediate tonsillectomy: indications for use as first-line surgical management of peritonsillar abcess (quinsy) and parapharyngeal abcess. J Laryngol Otol. 2010 Oct;124(10):1085-90.

4. Sandeep ST, Shivram S, Prakash BG. Quinsy tonsillectomy - a safe procedure. Journal of Evolution of Medical and Dental Science 2013;2(10):1447-51.

5. Simon LM, Matijasec JW, Perry AP. Pediatric peritonsillar abcess: Quinsy ie versus interval tonsillectomy. Int J Pediatr Otorhinolaryngol. 2013 Aug;77(8):1355-8.

6. Windfur JP, Remmert S. Trends and complications in the management of peritonsillar abcess with emphasis on children. HNO. 2005 Jan;53(1):46-57.

7. Windfuhr JP. Indications for tonsillectomy stratified by the level of evidence. GMS Curr Top Otorhinolaryngol Head Neck Surg. 2016 Dec 15;15:Doc09.

8. Andres HT, Hirt R, Statz K, Knipping S. Necrotizing fasciitis due to a peritonsillar abcess. HNO. 2013 Jun; 61(6):510-5.

9. Suzuki M, Ueyama T, Mogi G. Immediate tonsillectomy for peritonsillar abcess. Auris Nasus Larynx. 1999 Jul;26(3):299-304. 